Egyptian J. of Nutrition Vol. XXXV No. 1 (2020)

\title{
Evaluation of gluten-free noodles fortified by Spirulina algae
}

\section{Youssef M. Riyad(1), Mai M.M. Naeem ${ }^{(2)}$ and Salwa Slama(2)}

\author{
(1)Food Science Department, Faculty of Agriculture \\ Cairo University, Giza, Egypt. \\ (2)Department of Special food and nutrition, Food Technology \\ Research Institute, Agricultural Research Center, Giza, Egypt.
}

\begin{abstract}
Spirulina is a unique algae. It is very rich in nutrients. Therefore, gluten-free noodles made from potato flour was fortified to raise its nutritional value by adding 5,10 and $15 \%$ spirulina algae, as it is a suitable food for people suffering from celiac disease. The chemical composition of the spirulina algae, potato flour and gluten free noodles were determined. Vitamins, minerals, heavy metals, amino acids, pigments contents and in vitro protein digestibility were determined. The sensory characteristics of gluten-free noodles fortified with spirulina algae were also evaluated. The results indicated that heavy metals contents of spirulina algae (arsenic, cadmium, lead and mercury) were under the permeable limits according to the Egyptian Standards. The results indicated that the spirulina algae was rich in vitamins (with highest contain of inositol, $57.78 \mathrm{mg} / 100 \mathrm{~g}$ ), minerals (P 2100, K 1996, Ca 728 and Fe 438 $\mathrm{mg} / 100 \mathrm{~g}$ ), from the determined pigments phycocyanin pigment showed the highest content (13.85\%) and chlorophyll (1.5\%). The total essential amino acids and non-essential amino acids of the spirulina algae were found approximately $38.97 \%$ and $61.05 \%$ of
\end{abstract}




\section{Youssef M. Riyad, Mai M.M. Naeemand Salwa Slama}

protein content, respectively. Addition levels of $5 \%, 10 \%$ and $15 \%$ of spirulina algae to potato flour led to increase the contents of protein by about $24 \%, 49 \%$ and $73 \%$ respectively, Ca by 66,275 and $423 \%$ respectively, $P$ by 528,1192 and $1734 \%$ respectively, $K$ by 40,84 and $159 \%$ respectively, $\mathrm{Fe}$ by 348,576 and $952 \%$ respectively and in vitro protein digestibility values by 11,21 and $32 \%$ respectively compared to control sample. Results of the sensory evaluation revealed that addition of spirulina algae powder to potato flour at levels up to $15 \%$ could be recommended, since all the produced noodles scored higher values for all the evaluated sensory characteristics compared to control sample.

\section{Introduction}

Spirulina is a microalgae rich in protein content that reached to $70 \%$, so many nutritionists consider it an unconventional food source (Benahmed-Djilali, 2012). The algae could play an important role in some countries to meet the challenge of self-sufficiency of food and also have other functions such as treatment of some diseases (Fox, 1999).

Blue or green filamentous spirulina (microalgae) is a source of high biological value because it is considered a rich source of protein, vitamins, especially vitamin A and vitamin B12 and rich in minerals, especially iron, as well as it rich in essential fatty acids especially $y$-linolenic acid, which are very important in the synthesis of prostaglandins (Habib et al., 2008).

Spirulina contains many compounds that have antioxidant activity both in vitro and in vivo, such as carotene, alpha-tocopherol, phycocyanin, xanthophyll and phenolic compounds (Mao et al., 2005 and Patel et al., 2006). 
Egyptian J. of Nutrition Vol. XXXV No. 1 (2020)

Spirulina contains a complete protein with a high digestibility index, where the proportion of protein up to about $60 \%$. It contained all the essential amino acids and is one of the most nutrient sources rich in contents of beta-carotene, gamma linolenic fatty acid, vitamins B, minerals, trace elements, enzymes and chlorophyll as well as other valuable nutrients such as carotenoids, sulfolipids, glycolipids, phycocyanin, superoxide dismutase, RNA and DNA (Henrikson, 2010; Moorhead et al., 2011 and Parry, 2014). Micro-algae can be a sustainable alternative as coloring agents, resulting in products similar to vegetable-based pasta that presents nutritional advantages over synthetic colorings (Fradique et al., 2010).

One of the applications where spirulina has been used in human food is instant noodles for children ( $X u, 1993)$. Noodles is a food product that most people of all ages love and prefer (Keyimu, 2013 and Martin et al., 2004).

Celiac disease (CD) is a digestive disease that damages the small intestine and interferes with absorption of nutrients from food. Celiac disease is an ailment caused by an abnormal immune response to gluten proteins in wheat, rye, barley and possibly oats products. About $1-2 \%$ of the world's population suffers from this disease (Reilly et al., 2011). When celiac patients eat any food that contains gluten protein, this leads to villi atrophy from the small intestine, causing severe stomach pain, swelling, diarrhea and weight loss. It was also noted that these patients suffer from a lack of micronutrients due to the failure of absorption by the small intestine (Green and Cellier, 2007).

Some scientists have studied the effect of adding nutrients such as dietary fiber, vitamins and minerals from natural sources on the quality of pasta noodles (Kulkarni et al., 2012). Potato is an 


\section{Youssef M. Riyad, Mai M.M. Naeemand Salwa Slama}

important food crop where the world produces about 300 million metric tons annually (International Potato Center 2015).

The objective of this investigation was to study the effect of added spirulina algae as source of protein on physico-chemical characteristics, cooking quality and sensory properties of cooked gluten free noodles.

\section{Materials and methods}

Materials:

The blue green algae Spirulina platensis (free from impurities like pesticides, rodent hairs and insect fragments) was obtained from Algal Biotechnology Unit, National Research Centre, Dokki, Giza, Egypt. Potato flour was purchased from the local market in Giza, Egypt.

\section{Methods:}

\section{Chemical analysis}

Spirulina algae, potato flour and gluten free noodles were analyzed for its moisture, ash, protein, crude fiber and fat according to the methods of AOAC (2005). Nitrogen free extract (N.F.E.) was calculated by difference.

\section{Analytical methods of heavy metals in spirulina}

The determination of arsenic, cadmium and lead in spirulina sample was performed according to the methods described by Haeng-Shin et al., (2006).

\section{Determination of phytopigments and vitamins}

Phytopigments and vitamins (Thiamine, riboflavin, niacin, pyridoxine, cobalamin, folic acid, inositol, E, K, pantothenate and 
Egyptian J. of Nutrition Vol. XXXV No. 1 (2020)

biotin) were determined by the HPLC system method according to AOAC (2005).

Processing of gluten free noodles fortified by spirulina algae

Gluten free noodles fortified by spirulina algae formulas were prepared using a mixture of commercial potato flour, water and different ratio of spirulina algae $(5,10$ and $15 \% \mathrm{w} / \mathrm{w})$ as shown in Table 1. The gluten free noodles with and without spirulina algae (control) were prepared according to Owen (2001) and then packed in polyethylene bags and stored at room temperature for 6 months.

Cooking quality of gluten free noodles fortified by spirulina algae

Cooking losses

The weight gain and cooking loss of gluten free noodles fortified by spirulina algae were determined according to the method described by Lai (2002).

Sensory evaluation of cooked gluten free noodles fortified by spirulina algae

The sensory evaluation was carried out in order to get consumer response for overall acceptability of the gluten free noodle fortified by spirulina algae compared to the traditional noodle. Ten panelists from Food Technology Research Institute, Agricultural Research Center evaluated the sensory characteristics of the cooked noodles, i.e., texture, taste, color, and overall acceptability according to the method of Jayasena et al., (2008). 


\section{Youssef M. Riyad, Mai M.M. Naeemand Salwa Slama}

\section{In vitro protein digestibility}

In vitro protein digestibility of gluten free noodle and gluten free noodle fortified by spirulina algae were carried out using the method of Mertz et al. (1983).

\section{Statistical analysis}

All the obtained data were subjected to statistical analyses at least significant difference (L.S.D. at 0.05 level). Analysis of variance was used to compare between means by Duncan multiple range at significance $5 \%$. Means with different letters are significantly different. ANOVA was carried out by Statistical Analysis System SAS Program, (1996).

\section{Results and discussion}

Vitamins, minerals, heavy metals and pigments contents of spirulina algae

The results presented in Table 2 indicated that heavy metals contents of spirulina algae (arsenic, cadmium, lead and mercury) were under the permeable limits according to the Egyptian Standards for heavy metals (2007). These results are in agreement with Haeng-Shin et al. (2006). These results revealed that obtained spirulina algae could be considered healthy material and could be used in food products.

Spirulina algae as indicated in Table 2 was found to be contained B1, B2, B3, B6, B12, folic acid, pantothenate, biotin, inositol, $\mathrm{E}$ and $\mathrm{K}$ vitamins. Inositol showed the highest content (57.78 $\mathrm{mg} / 100 \mathrm{~g})$, also biotin content was the lowest $(8.52 \mu \mathrm{g} / 100 \mathrm{~g})$. These results are in agreement with Sharoba (2014) andVijayarani et al. (2012) they reported that spirulina contains complete vitamin B 


\section{Egyptian J. of Nutrition Vol. XXXV No. 1 (2020)}

groups as well as vitamins $\mathrm{A}, \mathrm{E}, \mathrm{H}, \mathrm{K}$ and they also found that inositol is the highest. While, Fox (1993) reported that spirulina contain vitamin B12 more than cow liver.

Concerning minerals contents, the results presented in the same Table indicated that $P$ showed the high amounts (2100 $\mathrm{mg} / 100 \mathrm{~g})$, followed by $\mathrm{k}(1996 \mathrm{mg} / 100 \mathrm{~g})$, then $\mathrm{Ca}(728 \mathrm{mg} / 100 \mathrm{~g})$ and finally Fe (438 mg/100g). However, the lowest value was that of $\mathrm{Mg}$ (74 mg/100g). These results are in agreement with those obtained by Shimamatsu (2004) and Branger et al. (2003). They reported that spirulina is an excellent source of minerals and it contains essence minerals like calcium, magnesium, potassium, phosphorus, iron, and zinc. Fox (1993) reported that spirulina contain calcium more than milk.

The same results showed also the presence of some phytopigments ( $\beta$-carotenoids, xanthophylls, zeaxanthin, chlorophyll and phycocyanin). However, phycocyanin showed the highest content (13.85\%)followed by chlorophyll (1.5\%). Zeaxanthin recorded the lowest content $(119 \mu \mathrm{g} / 100 \mathrm{~g})$. The blue green color of algae Spirulina platensis could be related to phycocyanin and chlorophyll phytopigments. These results are in agreement with those obtained by Fox (1993) and Sharoba (2014) which reported that spirulina platensis contained phycocyanin.

Phycocyanin is a nontoxic blue pigment in Spirulina and can act as a free radical scavenger and has a powerful antioxidant. Studies have shown that phycocyanin can exert a wide range of anti inflammatory effects. It has been claimed that consumption of Spirulina is beneficial to health due to its chemical composition. Dolly 


\section{Youssef M. Riyad, Mai M.M. Naeemand Salwa Slama}

(2014) reported that the anti-oxidant phycocyanin can only be found in spirulina.

\section{Amino acids contents of potato flour and spirulina algae}

The results presented in Table $\mathbf{3}$ indicated that potato flour and spirulina algae contained approximately same percentages of total essential amino acids (36.07 and $38.97 \%$ of protein content, respectively). Spirulina algae was found to contain isoleucine, leucine, lysine, methionine and tryptophan amino acids in percentages higher than those of potato flour, while the reverse was observed for phenylalanine, threonine and valine amino acids. Concerning non-essential amino acids, it was also found that potato flour and spirulina algae contained approximately the same percentage (63.95 and $61.05 \%$ of protein content, respectively). However, spirulina algae was found to contain higher percentage of alanine, arginine, cysteine, glycine and proline amino acids than those of potato flour. The reverse was observed for aspartic, glutamic, histidine, serine and tyrosin amino acids. Vijayarani et al. (2012) found that spirulina contains all the essential amino acids in fairly high amounts. It contains 18 of the 20 known amino acids and it is an excellent source of proteins with high quality. Mudambi and Rajagopal (1990) mentioned that potato protein has particularly favorable lysine content in comparison with cereal proteins, whose amino acid scores are much lower. Murray et al. (1998) reported that the basic role of potato protein in nutrition is the contribution to sufficient amounts of essential amino acids for protein endogenous synthesis by human body. 
Egyptian J. of Nutrition Vol. XXXV No. 1 (2020)

Chemical composition of raw materials and gluten free noodles fortified by different concentrations of spirulina algae and in vitro protein digestibility

The results presented in Table $\mathbf{4}$ indicated that spirulina algae contained high amount of protein, fat and crude fiber compared to potato flour, while ash content was found to be approximately the same. Potato flour contained N.F.E. higher than that of spirulina algae. The protein content of spirulina algae represent about tenfold compared to potato flour. So, it could be added to potato flour to raise the protein content. These results are in agreement with those reported by Shah (2001) who mentioned that spirulina is a blue multicellular bacterium which used as a food source from ancient times, and the protein content reaches $55 \%$ to $70 \%$ based on dry weight.Spolaore et al., (2006) reported that spirulina is an excellent source of proteins, it is complete proteins in comparison with other protein sources which have very negative properties. Vijayarani et al., (2012) found that spirulina contained protein (62.84\%) higher than any other natural food. However, potato flour was reported to contain $6.9 \%$ protein (Singh et al., 2007).

However gluten free noodleswere prepared using potato flour which mixed with spirulina algae at level of 5,10 and $15 \%$ to be suitable for celiac disease. The chemical components of the resulted gluten free noodle were determined and the results are presented in the same Table. From these results it could be observed that addition of spirulina algae lead to increase the protein contents of the gluten free noodle by about $24 \%, 49 \%$ and $73 \%$ for addition levels of $5 \%$, $10 \%$ and $15 \%$, respectively compared to control gluten free noodle. Fat content, was also increased by about $40 \%, 81 \%$ and $121 \%$ and ash increased by $62 \%, 80 \%$ and $120 \%$ for the same addition levels, respectively compared to control gluten free noodle. However, slightly 


\section{Youssef M. Riyad, Mai M.M. Naeemand Salwa Slama}

increase was observed for crud fiber contents of the prepared gluten free noodle which contained spirulina alga. N.F.E. contents of the resulted gluten free noodle were decreased by about $4 \%, 8 \%$ and $12 \%$ with addition of spirulina alga at levels of 5,10 and $15 \%$, respectively compared to control gluten free noodle. Similar results were reported for noodles made of composite flour of wheat, two microalgae flours (Chlorella vulgaris and Spirulina platensis), and a seaweed flour (Eucheuma cottonii) (Kumoro et al., 2016).

Moreover the protein contents of the gluten free noodles and gluten free noodles fortified by different concentrations of spirulina algae were evaluated for its digestibility (in vitro) and the results are shown in the same Table. The results showed that in vitro protein digestibility value of the gluten free noodles was $61.32 \%$. Adding spirulina algae with 5, 10 and $15 \%$ led to increase the in vitro protein digestibility values by about 11,21 and $32 \%$, respectively. The in vitro protein digestibility values increased by increasing the addition of spirulina algae. Protein contents in the fortified noodles were found to be increased significantly with the increase in the added spirulinapowder, the increased in protein content could be due to the high content of protein in spirulina (64.4\%). Our results are in agreement with those reported by (Tomaselli, 2004; Marco et al., 2014 and Ghaly et al., 2015). Also, these results are in agreement with Saharan and Jood (2017) which reported that adding spirulina to fortify bread led to increase in vitro protein digestibility values.

\section{Mineral contents of gluten free noodles fortified by spirulina algae}

Spirulina is an excellent source of minerals and it contains essence minerals like calcium, magnesium, potassium, phosphorus, iron, and zinc (Branger et al., 2003). The mineral contents of the 


\section{Egyptian J. of Nutrition Vol. XXXV No. 1 (2020)}

gluten free noodleswhich prepared by mixing of potato flour with spirulina algae at levels of 5, 10 and $15 \%$ were determined and the obtained results are presented in Table 5. Form these results it could be observed that addition of spirulina alga to potato flour lead to increase $\mathrm{Ca}$ contents of the gluten free resulted noodles by about 66 , 275 and 423\%, P contents by about 528, 1192 and 1734\%, K contents by about 40,84 and $159 \%$ and Fe by about 348, 576 and $952 \%$ for addition levels of 5,10 and $15 \%$, respectively compared to the control gluten free noodles. Mg contents of control noodle and other treatments which contained the same levels of spirulina algae were found to be approximately the same. These results revealed that spirulina algae cold be considered good source for minerals. These results are in agreement with Carolin et al., (2015).

\section{Cooking quality of gluten free noodles fortified by spirulina algae}

Cooking losses are an important indicator of the overall spaghetti cooking performance for both consumers and industry, being mainly influenced by dissolving and releasing gelatinized starches from the surface of pasta through cooking water (Brennan et al., 2003). The results presented in Table 6 indicated also that there are small significant differences in cooking loss and water absorption between the gluten free noodles samples that containing spirulina algae at levels of 5,10 and $15 \%$ and the control sample. While, volume increase values were higher than those of control sample. Volume increase values were increased by about 39, 62 and $87 \%$ for the same addition levels of spirulina algae, respectively. These results may be attributed to the ability of the alga to absorb water and retain it in the protein-starch net as explained by Prabhasankar et al., (2009), who mentioned that the addition of dried seaweeds to pasta, led to increase the volume of the resulted 


\section{Youssef M. Riyad, Mai M.M. Naeemand Salwa Slama}

product which being related to the hydration afforded by the hydrocolloids present in the seaweed powder.

\section{Sensory evaluation of the gluten free noodles fortified by spirulina algae}

From the results presented in Table 7 it could be observed that control samples (gluten free noodles) and samples fortified with 5,10 and $15 \%$ of spirulina algae were found to be significantly different for their appearance, taste, color, odor, firmness and total acceptability. However, the gluten free noodles sample which fortified by $10 \%$ of spirulina algae recorded the highest values for the evaluated characteristics compared to other treatments followed by the gluten free noodles which fortified by $5 \%$ of spirulina algae. The gluten free noodles sample fortified by $15 \%$ of spirulina algae recorded high values for all the evaluated characteristics compared to control sample with exception of appearance. These results revealed that addition of spirulina algae to potato flour at levels up to $15 \%$ could be recommended, since all the produced noodles scored higher values for all the evaluated characteristics compared to control sample.

These results are in agreement with Abd El-Salam et al., (2017). They found that instant noodles and crackers with addition of spirulina algae till level of $10 \%$ resulted very good overall acceptability and with $15 \%$ addition level in the resulted products showed good overall acceptability. 
Egyptian J. of Nutrition Vol. XXXV No. 1 (2020)

\section{Conclusion}

The results showed that using 5,10 and $15 \%$ of the spirulina alga with potato flour was able to prepare noodles with high nutritional value in terms of protein, minerals, vitamins and essential amino acids. Meanwhile, these noodles are gluten-free and suitable for people suffering from celiac disease.

\section{Acknowledgement}

We sincerely express my indebtedness to Dr. Ghada Mohamed Youssef, Professor of Food Technology, Department of Special Food and Nutrition, Food Technology Research Institute, Agricultural Research Center, Giza, Egypt, for her valuable guidance throughout this work.

Table 1. Formula of gluten free noodles fortified byspirulina algae prepared from potato flour and different ratio of spirulina algae.

\begin{tabular}{l|c|c|c|c}
\hline \multirow{2}{*}{ Ingredients(g) } & \multicolumn{4}{|c}{ Treatments } \\
\cline { 2 - 5 } & Control & $5 \%$ & $10 \%$ & $15 \%$ \\
\hline Potato flour & 967.6 & 917.6 & 867.6 & 817.6 \\
\hline Spirulina algae & - & 50 & 100 & 150 \\
\hline Guar gum & 2.4 & 2.4 & 2.4 & 2.4 \\
\hline Salt & 30 & 30 & 30 & 30 \\
\hline
\end{tabular}




\section{Youssef M. Riyad, Mai M.M. Naeemand Salwa Slama}

Table 2. Vitamins, minerals, heavy metals and phytopigments contents ofspirulina algaefor each of $100 \mathrm{~g}$ (on dry weight basis).

\begin{tabular}{|c|c|c|c|c|c|}
\hline \multicolumn{2}{|l|}{ Vitamins } & \multicolumn{2}{|c|}{ Minerals (mg) } & \multicolumn{2}{|c|}{ Phytopigments } \\
\hline Components & Content & Components & Content & Components & Content \\
\hline $\mathrm{B} 1$ (mg) & 5.25 & $\mathrm{Ca}$ & 728 & $\begin{array}{c}\beta-\text { carotenoids } \\
(\mu \mathrm{g})\end{array}$ & 240 \\
\hline B2 (mg) & 4.84 & $P$ & 2100 & $\begin{array}{c}\text { Xanthophylls } \\
(\mu g)\end{array}$ & 281 \\
\hline B3 (mg) & 16.99 & K & 1996 & $\begin{array}{l}\text { Zeaxanthin } \\
(\mu g)\end{array}$ & 119 \\
\hline B6 (mg) & 0.92 & $\mathrm{Mg}$ & 74 & $\begin{array}{c}\text { Chlorophyll } \\
\text { (\%) }\end{array}$ & 1.500 \\
\hline $\mathrm{B} 12(\mu \mathrm{g})$ & 190 & $\mathrm{Fe}$ & 438 & $\begin{array}{c}\text { Phycocyanin } \\
(\%)\end{array}$ & 13.85 \\
\hline Folic acid (mg) & 8.89 & \multirow{2}{*}{\multicolumn{2}{|c|}{ Heavy metals (ppm) }} & & \\
\hline Pantothenate $(\mu \mathrm{g})$ & 140 & & & & \\
\hline Biotin $(\mu g)$ & 8.52 & Arsenic & $<0.09$ & & \\
\hline Inositol (mg) & 57.78 & Cadmium & $<0.04$ & & \\
\hline $\mathrm{E}(\mathrm{mg})$ & 9.62 & Lead & $<0.04$ & & \\
\hline $\mathrm{K}(\mu \mathrm{g})$ & 1135 & Mercury & $<0.006$ & & \\
\hline
\end{tabular}


Egyptian J. of Nutrition Vol. XXXV No. 1 (2020)

Table 3. Amino acids content of potato flour and spirulina algae (\% of protein).

\begin{tabular}{c|c|c}
\hline \multicolumn{3}{|c|}{ Essential amino acids } \\
\hline \multicolumn{3}{|c}{ Potato flour } \\
\hline Isoleucine & 3.93 & 6.57 \\
\hline Leucine & 5.76 & 7.78 \\
\hline Lysine & 3.91 & 4.56 \\
\hline Methionine & 0.97 & 2.45 \\
\hline Phenylalanine & 6.22 & 4.50 \\
\hline Threonine & 5.67 & 4.78 \\
\hline Valine & 8.91 & 6.40 \\
\hline Tryptophan & 0.70 & 1.93 \\
\hline Total & 36.07 & 38.97 \\
\hline Alanine & Non-essential amino acids & 7.33 \\
\hline Arginine & 3.90 & 7.73 \\
\hline Aspartic & 4.43 & 11.25 \\
\hline Cysteine & 18.16 & 1.21 \\
\hline Glutamic & 0.80 & 13.70 \\
\hline Glycine & 14.98 & 5.23 \\
\hline Histidine & 4.80 & 2.71 \\
\hline Proline & 3.35 & 4.39 \\
\hline Serine & 3.85 & 4.16 \\
\hline Tyrosin & 5.70 & 3.34 \\
\hline Total & 3.98 & \\
\hline
\end{tabular}




\section{Youssef M. Riyad, Mai M.M. Naeemand Salwa Slama}

Table 4. Chemical composition of raw material and gluten free noodles fortified by different concentrations of spirulina algae and In vitro protein digestibility $(\mathrm{g} / 100 \mathrm{~g}$ on dry weight basis).

\begin{tabular}{|c|c|c|c|c|c|c|c|}
\hline \multicolumn{2}{|c|}{ Components } & Protein & Fat & N.F.E.* & Ash & $\begin{array}{l}\text { Crude } \\
\text { fiber }\end{array}$ & $\begin{array}{l}\text { In vitro protein } \\
\text { digestibility } \\
(\%)\end{array}$ \\
\hline \multicolumn{2}{|c|}{ Potato flour } & $\begin{array}{c}6.710 \\
\pm 0.162 b\end{array}$ & $\begin{array}{c}0.15 \\
\pm 0.013 b\end{array}$ & $\begin{array}{c}83.4 \\
\pm 0.216 a\end{array}$ & $\begin{array}{c}6.22 \\
\pm 0.025 b\end{array}$ & $\begin{array}{c}3.52 \\
\pm 0.165 b\end{array}$ & - \\
\hline \multicolumn{2}{|c|}{ Spirulina algae } & $\begin{array}{c}64.4 \\
\pm 0.0 a\end{array}$ & $\begin{array}{c}6.48 \\
\pm 0.0 a\end{array}$ & $\begin{array}{l}15.12 \\
\pm 0.0 \mathrm{~b}\end{array}$ & $\begin{array}{c}6.75 \\
\pm 0.01 a\end{array}$ & $\begin{array}{c}7.27 \\
\pm 0.02 a\end{array}$ & - \\
\hline \multicolumn{2}{|c|}{$\begin{array}{c}\text { Gluten free } \\
\text { noodles }\end{array}$} & $\begin{array}{c}10.42 \\
\pm 0.00 \mathrm{~d}\end{array}$ & $\begin{array}{c}0.68 \\
\pm 0.06 \mathrm{~d}\end{array}$ & $\begin{array}{c}85.01 \\
\pm 0.06 \mathrm{a}\end{array}$ & $\begin{array}{c}0.71 \\
\pm 0.02 d\end{array}$ & $\begin{array}{c}3.16 \\
\pm 0.06 d\end{array}$ & $\begin{array}{c}61.32 \\
\pm 0.62 d\end{array}$ \\
\hline \multirow{3}{*}{$\begin{array}{l}\text { Gluten } \\
\text { free } \\
\text { noodles } \\
\text { fortified } \\
\text { by } \\
\text { spirulina } \\
\text { algae }\end{array}$} & $5 \%$ & $\begin{array}{r}12.96 \\
\pm 0.06 \mathrm{c}\end{array}$ & $\begin{array}{c}0.95 \\
\pm 0.00 \mathrm{c}\end{array}$ & $\begin{array}{r}81.59 \\
\pm 0.02 b\end{array}$ & $\begin{array}{r}1.15 \\
\pm 0.00 c\end{array}$ & $\begin{array}{r}3.35 \\
\pm 0.00 \mathrm{c}\end{array}$ & $\begin{array}{c}68.17 \\
\pm 0.13 c\end{array}$ \\
\hline & $10 \%$ & $\begin{array}{r}15.49 \\
\pm 0.04 b\end{array}$ & $\begin{array}{c}1.23 \\
\pm 0.08 \mathrm{~b}\end{array}$ & $\begin{array}{c}78.47 \\
\pm 0.01 \mathrm{c}\end{array}$ & $\begin{array}{c}1.28 \\
\pm 0.02 b\end{array}$ & $\begin{array}{c}3.53 \\
\pm 0.02 b\end{array}$ & $\begin{array}{r}74.47 \\
\pm 0.55 b\end{array}$ \\
\hline & $15 \%$ & $\begin{array}{c}18.03 \\
\pm 0.00 \mathrm{a}\end{array}$ & $\begin{array}{r}1.50 \\
\pm 0.02 a\end{array}$ & $\begin{array}{l}75.18 \\
\pm 0.00 \mathrm{~d}\end{array}$ & $\begin{array}{r}1.56 \\
\pm 0.08 \mathrm{a}\end{array}$ & $\begin{array}{c}3.73 \\
\pm 0.00 \mathrm{a}\end{array}$ & $\begin{array}{r}81.04 \\
\pm 0.24 a\end{array}$ \\
\hline
\end{tabular}

Values are meaning of three replicates $\pm S D$, number in the same column for each (potato flour and spirulina algae) and (Gluten free noodles) followed by the same letter is not significantly different at 0.05 level.

${ }^{*}$ N.F.E: Nitrogen free extract was calculated by difference. 
Egyptian J. of Nutrition Vol. XXXV No. 1 (2020)

Table 5. Mineral contents of gluten free noodle fortified by spirulina algae.

\begin{tabular}{c|c|c|c|c}
\hline \multirow{2}{*}{} & \multirow{2}{*}{$\begin{array}{c}\text { Gluten } \\
\text { free noodle }\end{array}$} & \multicolumn{3}{|c}{ Gluten free noodle fortified by spirulina algae } \\
\cline { 3 - 5 } & & $5 \%$ & $10 \%$ & $15 \%$ \\
\hline \multicolumn{5}{|c}{ Mineral contents $(\mathrm{mg} / 100 \mathrm{~g})$} \\
\hline $\mathrm{Ca}$ & 51.3 & 85.1 & 192.3 & 268.5 \\
\hline $\mathrm{P}$ & 19.70 & 123.7 & 254.5 & 361.2 \\
\hline $\mathrm{K}$ & 222.5 & 311.2 & 409.1 & 576.5 \\
\hline $\mathrm{Mg}$ & 60.27 & 61.02 & 61.29 & 62.87 \\
\hline $\mathrm{Fe}$ & 6.2 & 27.8 & 41.9 & 65.2 \\
\hline
\end{tabular}

Values are meaning of three replicates \pm SD, number in the same row followed by the same letter is not significantly different at 0.05 level.

Table 6. cooking quality of gluten free noodle fortified by spirulina algae.

\begin{tabular}{|c|c|c|c|c|}
\hline & \multirow{2}{*}{$\begin{array}{c}\text { Gluten } \\
\text { free noodle }\end{array}$} & \multicolumn{3}{|c|}{ Gluten free noodle fortified by spirulina algae } \\
\hline & & $5 \%$ & $10 \%$ & $15 \%$ \\
\hline \multicolumn{5}{|c|}{ Cooking quality (\%) } \\
\hline Cooking loss & $6.35 \pm 0.02^{d}$ & $7.14 \pm 0.16^{\mathrm{a}}$ & $6.98 \pm 0.17^{c}$ & $7.08 \pm 0.06^{b}$ \\
\hline Volume increase & $103.45 \pm 0.08^{d}$ & $144.25 \pm 0.02^{\mathrm{c}}$ & $167.40 \pm 0.48^{b}$ & $193.21 \pm 0.51^{a}$ \\
\hline Water absorption & $79.13 \pm 0.85^{d}$ & $83.43 \pm 0.70^{c}$ & $85.73 \pm 0.65^{b}$ & $89.76 \pm 0.25^{a}$ \\
\hline
\end{tabular}

Values are meaning of three replicates \pm SD, number in the same row followed by the same letter is not significantly different at 0.05 level. 


\section{Youssef M. Riyad, Mai M.M. Naeemand Salwa Slama}

Table 7. Sensory evaluation of gluten free noodle fortified by spirulina algae.

\begin{tabular}{|c|c|c|c|c|}
\hline \multirow{2}{*}{$\begin{array}{c}\text { Parameter } \\
(10)\end{array}$} & \multirow{2}{*}{ Glutenfree noodle } & \multicolumn{3}{|c|}{ Gluten free noodle fortified by spirulina algae } \\
\hline & & $5 \%$ & $10 \%$ & $15 \%$ \\
\hline Appearance & $8.60 \pm 0.87^{c}$ & $8.87 \pm 0.53^{b}$ & $9.25 \pm 0.49^{a}$ & $8.37 \pm 0.33^{d}$ \\
\hline Taste & $8.45 \pm 0.45^{d}$ & $8.80 \pm 0.62^{b}$ & $9.08 \pm 0.33^{a}$ & $8.60 \pm 0.22^{c}$ \\
\hline Color & $8.23 \pm 0.53^{d}$ & $8.96 \pm 0.65^{b}$ & $9.65 \pm 0.26^{a}$ & $8.86 \pm 0.45^{c}$ \\
\hline Odor & $8.80 \pm 0.63^{d}$ & $9.12 \pm 0.41^{b}$ & $9.40 \pm 0.25^{\mathrm{a}}$ & $9.02 \pm 0.31^{\mathrm{c}}$ \\
\hline Firmness & $8.60 \pm 0.66^{d}$ & $8.95 \pm 0.76^{b}$ & $9.50 \pm 0.17^{a}$ & $8.65 \pm 0.46^{c}$ \\
\hline $\begin{array}{c}\text { Total } \\
\text { acceptability }\end{array}$ & $8.57 \pm 0.63^{d}$ & $8.96 \pm 0.59^{b}$ & $9.44 \pm 0.30^{\mathrm{a}}$ & $8.76 \pm 0.29^{c}$ \\
\hline \multicolumn{5}{|c|}{ Values are meaning of three replicates $\pm S D$, number in the same } \\
\hline
\end{tabular}


Egyptian J. of Nutrition Vol. XXXV No. 1 (2020)

\section{References}

Abd El-Salam, A. M.; Morsy, O.M. and Abd El Mawla, E.M. (2017). Production and evaluation of crackers and instant noodles supplemented with spirulina algae. Curr. Sci. Int., 6(4): 908919.

A.O.A.C., (2005).

Official Methods of Analysis. Association of Official Analytical, Chemists 18th ed., Washington, DC, USA.

Benahmed-Dilali, A.(2012).

Analysis of technological skills of dates (Phoenix-dactylifera.L) enriched with Spirulina. Study of rheological, nutritional and antibacterial properties. Boumerdes, Algeria: M'hamed Bougara-Boumerdes University, PhD Thesis.

Branger, B.; Cadudal, J.L.; Delobel, M.; Ouoba, H.; Yameogo, P.; Ouedraogo, D.; Guerin, D.; Valea, A.; Zombre, C. and Ancel, P.(2003).

Spirulina as a food supplement in case of infant malnutrition in Burkina-Faso. Archives de Pédiatrie,10( 5): 424-431.

Brennan, C. S.; Kuri, V. and Tudorica, C. M. (2003). Inulin enriched pasta: effects on textural properties and starch degradation. Food Chemistry, 86:189-193. 


\section{Youssef M. Riyad, Mai M.M. Naeemand Salwa Slama}

Carolin, J.; Rosariom, J. and Mary Josephine, R. (2015).

Mineral profile of edible algae Spirulina platensis. Int.J.Curr.Microbiol.App.Sci., 4(1): 478-483.

Dolly Wattal Dhar (2014).

Biotechnological Potentials and Role of Cyanobacteria in Agriculture and Industry. Division of Microbiology Indian Agricultural Research Institute New Delhi-110012, India.

Egyptian Standards for Heavy Metals (2007).

Maximum levels for heavy metals parts 1-5: Maximum levels for lead, cadmium, mercury, arsenic in food.

Fox, D. (1993).

Health benefits of Spirulina and proposal for a nutrition test on children suffering from kwashiorkor and marasmus. In: Doumengue $F$, Durand Chastel $H$, Toulemont $A$, editors. Spiruline algue de vie. Bulletin de I'Institut Oc'eanographique Monaco, Mus'ee Oc'eanographique. Num'ero sp'ecial 12:179-85.

Fox, R.D. (1999).

Spirulina, Technique pratique et promesse", Edisud, Aix-enProvence: Ed. Sud. 
Egyptian J. of Nutrition Vol. XXXV No. 1 (2020)

Fradique, M.; Batista, A.; Nunes, M.; Gouveia, L.; Bandarra, N. and Raymundo, A. (2010).

Incorporation of Chlorella vulgaris and Spirulina maxima biomass on pasta products. Part 1: preparation and evaluation. Journal of Science Food Agriculture, 90: 16561664.

Ghaly, A.; Hammouda, A. and Hattab, M. (2015).

Development and sensory evaluation of spirulina chocolate chip oatmeal cookies. Int. J. Bioprocess and Biotechnol. Adv.1 (2): 63-73.

Green, P.H.R. and Cellier, C. (2007).

Celiac disease. New Engl. J. Med., 357,1731-1743.

Habib, M.; Parvin, M.; Huntington, T. and Hasan, M. (2008).

A review on culture, production and use of Spirulina as food for humans and feeds for domestic animals and fish. FAO Fisheries and Aquaculture Circular. No: 1034.

Haeng, Shin L., Yang Hee, C.; Seon, P.; K.Seung-Hee, O.; BokHee, K.; Tae Shik, H.; Meehye, K.; Jong Ok, L. and Choil, K. (2006).

Dietary exposure of the Korean population to arsenic, cadmium, lead and mercury. Journal of Food Composition and Analysis 19, S31-S37. 


\section{Youssef M. Riyad, Mai M.M. Naeemand Salwa Slama}

Henrikson, R. (2010).

Spirulina "World Food" How this micro algae can transform your health and our planet. Library of Congress Catalog Card Number: 89-091683, ISBN 1453766987, EIN-13 9781453766989. Published by Ronore Enterprises, Inc., USA.

\section{International Potato Center (2015).}

CIP annual report roots and tubers improving the lives of the poor.https://cipotato.org/publications/annual-report-2015roots-tubers-improving-lives-poor-embracing-sdgs-2015.

Jayasena, V.; Leung, P. and Nasar-Abbas, S. M. (2008).

Lupins for health and wealth. Proceedings of the 12th international Lupin conference, 13-18 sept. 2008, fremantle, Western Australia. International Lupin association, Canterbury, New Zealand. ISBN 0-86476-153-8.

Keyimu, X. G. (2013).

The Effects of Using Seaweed on the Quality of Asian Noodles. J Food Process Technol., 4(216), 2.

Kulkarni, S. S.; Desai, A. D.; Ranveer, R. C. and Sahoo, A. K. (2012).

Development of nutrient rich noodles by supplementation with malted ragi flour. International Food Research Journal, 19(1), 309-313. 
Egyptian J. of Nutrition Vol. XXXV No. 1 (2020)

Kumoro, A. C.; Johnny, D. and Alfilovita, D. (2016).

Incorporation of microalgae and seaweed in instant fried wheat noodles manufacturing: nutrition and culinary properties study. International Food Research Journal 23(2): 715-722.

Lai, H.M. (2002).

Effects of rice properties and emulsifiers on the quality of rice pasta. Journal of the Science of Food and Agriculture 82, 203216.

Mao, T.; Van de Water, J. and Gershwin, M. (2005).

Effects of a spirulina -based dietary supplement on cytokine production from allergic rhinitis patients. Journal of Medicinal Food, 8, 27-30.

Marco, E.R.D.; Steffolani, M.E.; Martĭnez, C.S. and León, A.E. (2014).

Effect of spirulina biomass on the technological and nutritional quality of bread wheat pasta. Food Science and Technology, 58: 102-108.

Martin, J. M.; Talbert, L. E.; Habernicht, D. K.; Lanning, S. P.; Sherman, J. D.; Carlson, G. and Giroux, M. J. (2004).

Reduced amylose effects on bread and white salted noodle quality. Cereal Chemistry, 81(2), 188-193. 


\section{Youssef M. Riyad, Mai M.M. Naeemand Salwa Slama}

Mertz, E.T.; Kireis, A.W. and Sxtell, J.D. (1983).

In vitro digestibility of protein in major food cereals. Feed Process, 32(5), 132-142.

Moorhead, K; Capelli, B. and Gerald, C.R. (2011).

Spirulina Nature's Super food. 3rd edition published by Cyanotech Corporation, 73-4460 Queen Kaahumanu Hwy \#102, Kailua-Kona, HI 96740, USA

Mudambi, R. and Rajagopal, M.V. (1990).

Role of potato in child nutrition. Indian Food Packer 10:25-32.

Murray, R. K.; Granner, D. K.; Mayes, P. A. and Rodwell, V. W. (1998).

Harper's Biochemistry. 24th ed. Appleton \& Lange. 848 p. ISBN 978- 0838536117

Owen, G. (2001).

Cereal Processing Technology. Cambridge: woodhead publishing.

Parry E.I.D. (India) Limited (2014).

Spirulina for Children. Parry Nutraceuticals Division. Dare House, 4th Floor, \# 234, N.S.C. Bose Road, Parrys Corner, Chennai - 600001, India. www.parrynutraceuticals.com. 
Egyptian J. of Nutrition Vol. XXXV No. 1 (2020)

Patel, A.; Mishra, S. and Glosh, P. (2006).

Antioxidant potential of C-phycocyanin isolated from cyanobacterial species Lyngbya phormidium and Spirulina sp. Indian Journal of Biochemistry and Biophysics, 43,25-31.

Prabhasankar, P.; Ganesan, P.; Bhaskar, N.; Hirose, A.; Nimishmol, S. and Lalitha, R.G. (2009).

Edible Japanese seaweed, wakame (Undaria pinnatifida) as an ingredient in pasta: Chemical, functional and structural evaluation. Food Chemistry, 115:501-508.

Reilly, N. R.; Aguilar, K.; Hassid, B. G.; Cheng, J.; DeFelice, A. R.; Kazlow, P.; Bhagat, G. and Green, P. H. (2011).

Celiac disease in normal weight - and overweight children: clinical features and growth outcomes following a gluten- free diet. J Pediatr Gastroenterol Nutr., 53(5),528 -531.

Saharan, V. and Jood, S. (2017).

Vitamins, minerals, protein digestibility and antioxidant activity of bread enriched with spirulina platensis powder. Int. J. Agric. Sci., 7 (3): 1292-1297.

SAS Program, (1996).

SAS/STAT User's Guide Release 6.12 edition. SAS Inst. Inc, Cary NC, USA 


\section{Youssef M. Riyad, Mai M.M. Naeemand Salwa Slama}

Shah, N.P. (2001).

Functional foods from probiotics and prebiotics. Food Technol., 55(11):46-53.

Sharoba, A. M. (2014).

Nutritional value of spirulina and its use in the preparation of some complementary baby food formulas. Journal of Agroalimentary Processes and Technologies, 20(4): 330-350

Shimamatsu, H. (2004).

Mass production of Spirulina, an edible microalga. Hydrobiologia, 512:39-44.

Singh, K.K.; Sahay, K.M.; Dange Mohini, M. and Patel, S. (2007). Development of process technology for preparation of readyto-eat puffed potato cubes. J. Agric. Eng.44 (2):241-249.

Spolaore, P.; Joannis-Cassan, C.; Duran, E. and Isambert, A. (2006).

Commercial applications of microalgae. J Biosci Bioen., 101(2):87-96.

Tomaselli, L. (2004).

The microalgal cell. In: Handbook of microalgal culture: biotechnology and applied phycology. , Amos Richmond (Ed.), Blackwell Publishing Ltd., pp. 3-19. 
Egyptian J. of Nutrition Vol. XXXV No. 1 (2020)

Vijayarani, D.; Ponnalaghu, S. and Rajathivya, J. (2012).

Development of value added extruded product using spirulina.

International Journal of Health Sciences and Research, 2(4): 42-47.

Xu, C.W. (1993).

An instant algal noodle and its production method, Chinese Patent CN1077857A.Technology, 3 (2), 79-88. 


\title{
Youssef M. Riyad, Mai M.M. Naeemand Salwa Slama
}

\section{تقييم النودلز الخالي من الجلوتين والمدعم بطحلب الاسبيرولينا}

\section{يوسف مصطفي رياض(') مي محمد مجدي نعيم(r) سلوي سلامة(r)}

\author{
(') قسم علوم الأغذية، كلية الزر اعة، جامعة القاهرة، الجيزة، مصر. \\ (†)قم بحوث الأغذية الخاصة و التغذية، معهذ بحوث تكنولوجيا الأغذية، مركز البحوث الزر اعية،

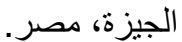 \\ الملخص العربي
}

يعتبر الاسبيرولينا طحلب غني جداً بالمغذيات. لذلك نم تدعيم النودلز المجز الته باستخدام

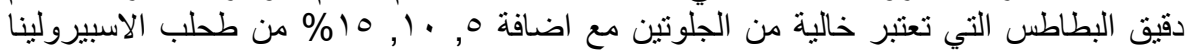

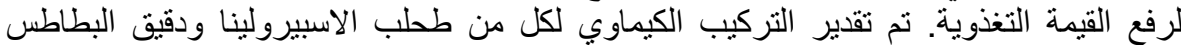

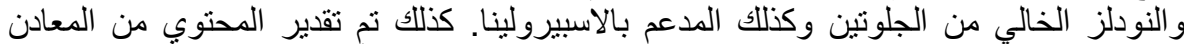

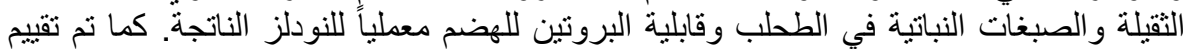

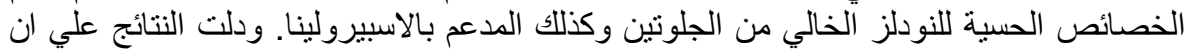

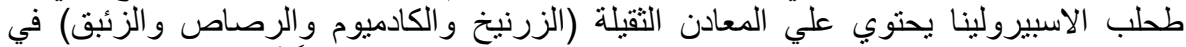

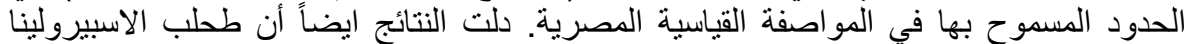

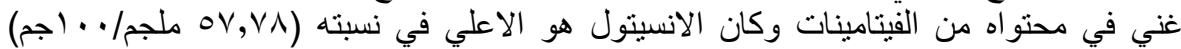

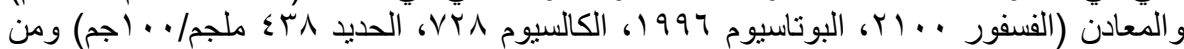

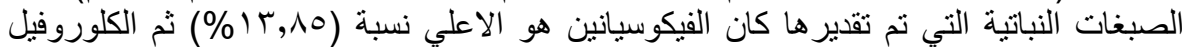

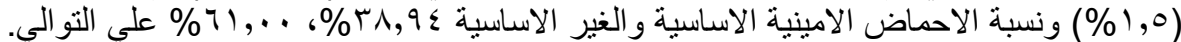

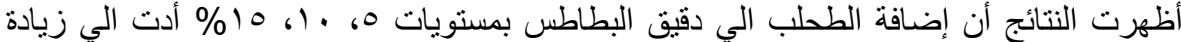

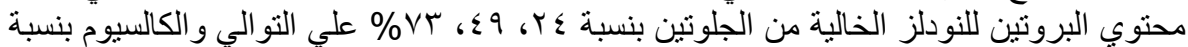

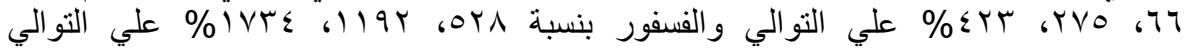

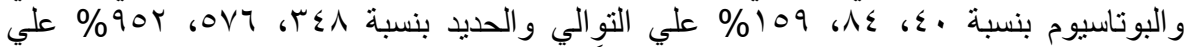

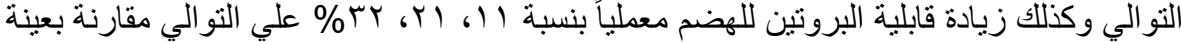

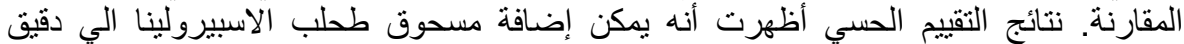

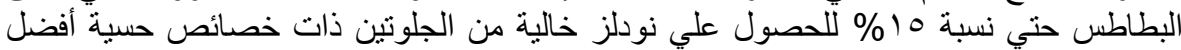

